\title{
Effects of a Reading Comprehension Program Children's Literature as a Didactic Resource
}

\author{
Freddy Duchimasa-Ochoa*, Inés Huiracocha-Ordóñez \\ Faculty of Philosophy, University of Cuenca, Cuenca, 010105, Azuay, Ecuador \\ Received January 1, 2021; Revised February 10, 2021; Accepted March 13, 2021
}

\section{Cite This Paper in the following Citation Styles}

(a): [1] Freddy Duchimasa-Ochoa, Inés Huiracocha-Ordóñez, "Effects of a Reading Comprehension Program Children's Literature as a Didactic Resource," Universal Journal of Educational Research, Vol. 9, No. 4, pp. 806 - 812, 2021. DOI: 10.13189/ujer.2021.090413.

(b): Freddy Duchimasa-Ochoa, Inés Huiracocha-Ordónez (2021). Effects of a Reading Comprehension Program Children's Literature as a Didactic Resource. Universal Journal of Educational Research, 9(4), 806 - 812. DOI: 10.13189/ujer.2021.090413.

Copyright $\bigcirc 2021$ by authors, all rights reserved. Authors agree that this article remains permanently open access under the terms of the Creative Commons Attribution License 4.0 International License

\begin{abstract}
International studies have shown that children have difficulties in correctly answering questions about previously read texts due to various factors that are related to reading processes, such as decoding and comprehension or difficulties related to these processes. Understanding written language is one of the most complex cognitive processes; in recent years, this topic has been studied extensively, in order to contribute to the development of reading comprehension skills. In this sense, the purpose of this research was to determine the effect of a reading comprehension program with the use of children's literature as a didactic resource, to develop the skills of reading comprehension. A pre-experimental type methodology was used, with a pretest-posttest design; For this, two previously selected narrative texts were used with their evaluation instruments, which were piloted, corrected and validated by experts in reading and literature. The study involved 33 seventh-grade children from elementary school, from an urban public school in the canton of Paute, in addition to five experts. The results indicate the relevance of the use of children's literature as a didactic resource to achieve reading comprehension, as well as, it supports the development of teaching interventions that include this type of resources and practices for its application in the dynamics of the classrooms.
\end{abstract}

Keywords Reading Comprehension, Children's Literature, Cognitive Processes, Skills, Intervention

\section{Introduction}

International studies have shown that children have difficulties in correctly answering questions about previously read texts (McNamarra, 2004; Caín, 2003: Muñoz and Ocaña, 2017), due to various factors that are related to reading processes such as decoding and understanding difficulties related to these processes (Gil and Flores, 2011). One of the main problems in Ecuadorian school education is related to the low levels of reading comprehension skills. The results report of the Third Regional Comparative and Explanatory Study (TERCE, for its initials in Spanish) of Latin America and the Caribbean, reflects that Ecuador is below the weighted average in terms of mastery of reading skills, from third to sixth year of basic education, (UNESCO, 2015). Regarding national studies, there is no data on assessments at the level of Basic General Education, however, studies at the high school level show that the level of mastery of this skill is low (INEVAL, 2019). Guerrero (2017) points out that there are factors that make today's students not read, or if they do, their comprehension is little or almost zero. Those factors are due to a lack of reading habit, money, time, will, as well as, the lack of linguistic proficiency, lack of comprehension skills, the obligation to read, among others.

Based on the above, it is considered justified to suggest a frame of reference on reading comprehension, its levels and abilities, the use of children's reading, and the development of these levels and skills. The following paragraphs discuss conceptions of reading, reading 
comprehension and their different levels of understanding. Then, a framework of children's literature and its importance in the development of reading comprehension skills is proposed. Finally, the goal of the study and the research questions are formulated.

\section{Conceptions of reading and reading comprehension}

Reading is not a simple decoding activity. Gutiérrez (2009) states that to read just to decipher signs is not enough . Reading is conceived as an activity of interaction between the subject and a text; in this process, several cognitive processes that activate the previous schemes are put into operation, the same ones that act as a frame of reference in the reading process (Millán, 2010). In this sense, reading is a configuration factor between linguistic proficiency and subsequent curricular and social learnings (Yubero and Larrañaga, 2010). Cassany, Luna, and Sanz (2003) define reading as a powerful learning tool, in which the acquisition of written code involves the development of higher cognitive abilities. Therefore, reading involves an exercise in discovery, walking curiously towards the unknown, exploring, nourishing, and generating your own ideas (Carrasco, 2003).

Reading allows us to access to new information and therefore gain knowledge. For Gil (2001) reading has a leading role in access to information that is why reading skills must be prioritized at school stages. In addition, it is essential during school life, because reading is essential to understand what is happening around us (Cassany, 2008), hence, we progress intellectually and emotionally, and become independent beings. Thus, ensuring that students become proficient readers is a priority today (Hagg, 2017).

Reading comprehension, as an intellectual activity, involves processes beyond the simple decoding of graphic units to sound and the recognition of letters, syllables or words Pellicer and Vernon (1993). Hence, to discern the meaning of reading comprehension, Palacios (2001) is used, who refers that the true meaning of a text is not in the meaning of a set of words that compose it, but it is only created when the relationship between the reader and the text has been established. In this sense, the reading's message never provides all the information, but the reader builds it with the necessary information. In short, reading comprehension is an ability to extract the meaning of a written text (Gómez, 2011; Herrera, Hernández, Valdés and Valenzuela, 2015; Flores and Gallego, 2017; Condemarín 2001).

\section{Reading comprehension levels}

Alliende and Condemarín (1986) define three levels for understanding a text, which are considered in a gradual order, from the most basic comprehension skills to the most complex ones.

The first level or literal level refers to the fundamental skills of recognizing and remembering (Herrera, et al.,
2015). It focuses on information that is explicitly exposed in the text (Gordillo and Flores, 2009). It helps to recognize keywords and phrases in the text, although it does not deepen or search for possibilities beyond its meaning, but only remains in the information provided first hand (Durango, 2017). The specific skills at this level fit into the recognition and location of explicit information in the text; detail recognition: characters, settings, names and key elements; identification of main and secondary ideas; cause-effect relationships, among others.

The second level or inferential level refers to deduction and inferential thinking skills, corresponds to the global understanding of the text, provided in implicit information or what Cassany calls "between the lines". At this level, the relationship with the social and cultural values of the context and with knowledge (Durango, 2017) becomes vitally important. The specific skills of this level are: inferences of details, according to conjectures; inferences from ideas not included; predicting events; interpretation of figurative language, among others (Gordillo and Flórez, 2009).

The third level or critical evaluative level refers to the abilities to make judgments about the text read, accept or reject the information, but with fundamentals. This level has an evaluative character in which the reader's knowledge is involved. Among its abilities are: the rejection or acceptance of information based on either reality or fantasy, according to the reader experience; validity and adequacy; comparison with other sources, among others (Herrera, et al., 2005).

\section{Importance of children's literature}

The term children's literature has several meanings. Among the best known, children's literature is understood as works written for children between four and fifteen years old. Cervera (1989) defines it as any production that has the word as a vehicle, with creative, aesthetic and artistic touches, and that is written for the child. Molina (2002) refers that literature has a transcendental role in people's reading comprehension since it is a resource that awakens their imagination and fantasy, increases their vocabulary, enriches their knowledge, develops the sense of aesthetic language, and allows the development of the language system (for example, lexical and syntactic consciousness), thus contributing to improving reading comprehension skills. Quintanal (2011) adds that it is "the best reading material for the elementary school child due to its adaptation to its evolutionary development, because it allows responding to the needs and concerns of the reader and because it ensures a certain quality" (p. 43).

\section{The present study}

The goal of this study is to determine the effect of the reading comprehension program with the use of children's literature as a teaching resource, designed to develop 
reading comprehension skills in seventh grade students of an urban public school in the canton Paute. Based on the study of the goal, the following research questions were asked: (1) To what extent does a reading comprehension program with children's literature as a didactic resource help in the development of reading comprehension skills?; (2) How do seventh grade children perform in reading comprehension skills?; and (3) Are there any differences in performance after the intervention in reading comprehension skills between boys and girls?

\section{Method}

\section{Participants}

The study included 33 children from the seventh year of elementary school, aged between 10 and 11 years (Mean $=$ 10.36; $\mathrm{SD}=0.48$ ), of which $54.45 \%$ were boys and $45.45 \%$ girls, who came from an urban public educational center in the Canton of Paute, Azuay province. In addition to the 33 schoolchildren, six experts in the field of reading and literature participated in the study. The panel of experts was made up of three students from a Master's program in Reading and Writing Pedagogy, from the University of Cuenca and three Professors of Language and Literature.

\section{Materials}

Two previously selected narrative texts were implemented with their respective assessment tools and the reading comprehension program focused on the use of children's literature.

\section{El almohadón de plumas}

To assess reading comprehension skills, the narrative text The Feather Cushion (Quiroga, 1917) was used. For this text, an assessment instrument was designed and validated to evaluate the reading comprehension skills of the 33 children, before the didactic intervention, that is, it is the pretest.

\section{Las medias de los flamencos}

To assess reading comprehension skills, the narrative text The flamingo stockings (Quiroga, 1918) was used, together with the designed and validated instrument, it was administered to the 33 children, once the intervention was completed, in order to measure the reading comprehension skills, that is, it is the posttest.

The proposed instruments were designed according to the content of the literary texts, as well as, they went through a suitable validation process with the participation of a panel of experts to validate their content and piloting to determine the viability. Regarding the texts, its content was in the field of children's literature. All were in prose and each one had an approximate length of 1250 to 1500 words. In Table 1, the skills that were evaluated in each instrument are disclosed.

Table 1. Evaluated skills

\begin{tabular}{ll}
\hline & \multicolumn{1}{c}{ Skills } \\
\hline 1 & Make predictions. \\
3 & Identify the main and secondary characters. \\
4 & Describe the characters. \\
5 & Identify the main idea. \\
6 & Gatch familiar ideas to new ones. \\
7 & Tell the story in your own words. \\
8 & Form opinions about what has been read. \\
9 & Write a paraphrase. \\
\hline
\end{tabular}

\section{Expert panel questionnaire}

An expert panel was organized to validate the content of the two reading comprehension assessment instruments (pretest and posttest). The experts had to answer the following questions individually:

1) Do you think this is a good question to measure the corresponding reading comprehension skill?

2) Do you agree that a child who has achieved the development of the corresponding reading comprehension skill should be able to answer this question correctly?

The questions asked in the expert questionnaire were intended to validate the content of the instruments for the pretest and posttest.

\section{Program}

Regarding the strategies to develop comprehension skills, the researchers designed a didactic sequence that includes stages before reading, during reading and after reading with a series of actions that are shown in Table 2.

\section{Design}

This research is pre-experimental, test / post-test design. As pointed out by Hernández, Fernández and Baptista (2014), since it is a chronological process, in which a pretest was initially applied; then the didactic process was carried out, supported by children's literature as a teaching resource. Finally, a posttest was implemented, in order to verify if there was improvement in the reading comprehension process. 
Table2. Applied sequence

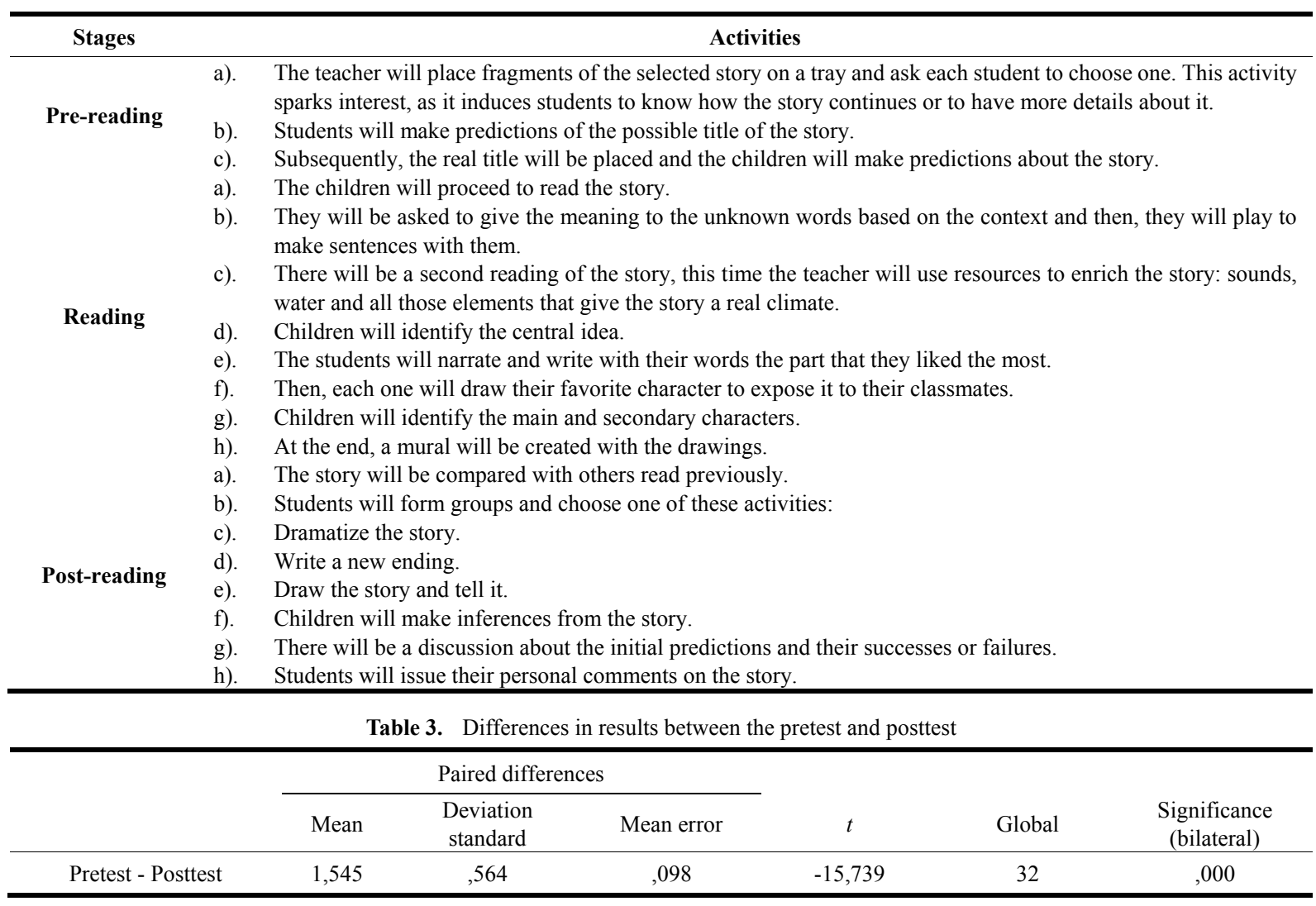

\section{Procedure}

During July, a panel of experts was organized. At the first session, they received oral and written instructions on how to complete the questionnaire, in addition, they received extra materials (narrative texts, assessment instruments and scoring criteria). A week later, the focus group was organized, in which the experts discussed the main concerns of the provided instruments, based on their individual responses. After the panel of experts, in September, a pilot study was carried out, where the researchers applied reading comprehension instruments to 10 schoolchildren from an urban public school in the canton Paute. Based on the results, the necessary changes were made to the instruments.

Before and after implementing the program, a series of evaluation instruments was applied to the 33 participants in the same order as described in the materials, in a 45-minute group session for each test. Two teachers of Language and Literature previously trained in each of the tests, carried out the evaluation.

The initial evaluation was carried out in the first week of September within school hours. Subsequently, in the second week, the intervention program was implemented ( 5 sessions of 45 minutes per week). In late December, the second instrument was applied. The research respected ethical values (informed consent, confidentiality or discrimination, free and the possibility of leaving the study at any stage).

\section{Results}

To determine the goals of study, that is, to determine the effect of the reading comprehension program with the use of children's literature as a didactic resource, designed to develop reading comprehension skills in seventh-grade students, the performance of children in the pretest and posttest, followed by the results on gender differences. For this, descriptive analysis was performed: average, standard deviation and levels of significance with the scores obtained of the applied tests in the pretest and posttest phases. These analyzes were carried out on the SPSS 20.0 computer software.

To answer research question 1, Table 3 presents the statistical results, where the results of the Student's t-analysis appear: first, the average difference between the pretest and posttest from 7.55 to 9.09 is $-1,545$., with a standard deviation of $.564 ;-15$ Student t-test. 739 ; Regarding the levels of significance, the calculations were performed with a significance level of 0.05 , which implies according to Hernández et al. (2014) that the researcher has $95 \%$ security to generalize without making mistakes and $5 \%$ against. The level of significance is .000 , which shows that, after completing the reading comprehension program, the students improved their skills significantly. 
Table 4 presents the results that answer research question 2, i.e. the average performance of children from the seventh grade of basic education in the pretest and in the posttest, supported on a qualifying scale of 0 to 10 (with 10 being the highest score). It is identified that the pretest score is 7.55 and after the intervention, the average obtained in posttest improved significantly to 9.09 .

Table 4. Means, number of students and standard deviation of the pretest and posttest

\begin{tabular}{cccc}
\hline & Mean & $\mathrm{N}$ & Standardesviation \\
\hline Pretest & 7,55 & 33 & 1,003 \\
Posttest & 9,09 & 33 &, 805 \\
\hline
\end{tabular}

The above is verifiable graphically, as observed in Figure 1, the results of the posttest in relation to the pretest are superior, which indicates an increase in the performance of children in reading comprehension activities, after the intervention.

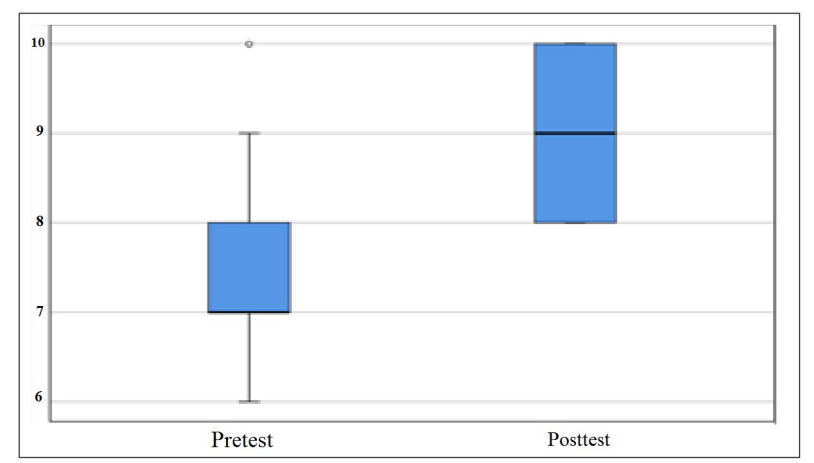

Figure 1. Comparative of the results between the pretest and posttest

To address research question 3, a multiple regression was performed, of the post-test data as a dependent variable and gender (boy and girl) as an independent variable. Table 4 shows the results of this multiple regression analysis, where it can be appreciated that there are no significant differences between boys and girls $(\mathrm{p}=.79)$.

Table 5. Linear regression model of the predictors of the Posttest scores

\begin{tabular}{ccccccc}
\hline & $\mathrm{b}$ & $\begin{array}{c}\text { Std. } \\
\text { Error. }\end{array}$ & Beta & $t$ & Global & Significance \\
\hline Gender &, 031 &, 113 &, 049 &, 272 &, 79 &, 000 \\
\hline
\end{tabular}

\section{Discussion and Conclusions}

The results obtained in the pretest have given way to investigating research mentioned in the literature review of this work, in which it is highlighted that reading is a connecting bridge between the known and the new information. Reading is essential in daily life, since it facilitates knowledge that transforms an individual into an independent human being with the capacity for intellectual and emotional progress; likewise, it is emphasized that reading is essential at the school stage because it allows us to understand the environment and everything that occurs in it (Cassany, 2008).

Although the pretest helped to identify the participants' average of reading comprehension of texts and to understand their difficulty in understanding a text. With this, what (Millán, 2010) stated was verified. He states that reading is an interactive activity between the subject and a text, and in this context, several cognitive processes operate to activate the previous schemas, which in turn acquire importance because they act as a frame of reference in the reading process.

At this point, it is of greatest importance to emphasize the understanding of texts. Phase covers a series of skills such as predicting, paraphrasing, making inferences, among others. Hence, many authors have investigated this field and its various ways of enriching it and even more so on how to promote it in students. Faced with this situation, it was determined to use children's literature as a teaching resource to improve reading comprehension level. Let us briefly remember that teaching resources are the support that a teacher needs to generate a meaningful learning.

Certainly, children's literature is an instrument that contributes positively to reading comprehension. Although seventh-year students work with several types of texts, it must be recognized that of all of them, only literary texts are those that allow them to go further, that is, to imagine, build and rebuild. Cervera (1989) conceives of children's literature as an "answer to the child's intimate needs" (p. 161). Therefore, when used, it contributes to the training process of an individual. The stories addressed in children's stories not only stop at a bunch of words that give an instruction, but starting from what is known and later inquiring "behind the lines" as Cassany (2006) mentions, these words gathered together acquire a capacity of sensitize, create and renew. Thus children, based on what is already known, will be able to rebuild and predispose themselves for a better learning.

Cassany (2006) states that "to understand it is necessary to develop various mental skills or cognitive processes: anticipate what a writing will say, contribute our previous knowledge ..." (p. 21). For this reason, the activities of the applied program have been executed in order to improve the skills mentioned in Table 1. Therefore, students become functional alphabets by not only narrating orally a reading but also understanding its meaning. Hence, it is confirmed that the application of the sequence was effective in improving the level of reading comprehension of texts in seventh grade children.

It should be emphasized that the resource used (children's literature) is considered by Chong-Siu Sánchez (2002) as one of the best means of fostering the love of reading and stimulate deep feelings in children, which is why it should be encouraged at an early age or from the beginning of education.

The results allow us to conclude that the implementation of the program constitutes an ideal resource that helps the 
development of the skills of each level of reading comprehension, since it has a cognitive, sensitizing, renewal and creative capacity. Through the reading comprehension program with various activities and didactic processes, children can be guided to develop certain skills such as the use and activation of previous knowledge, prediction, selection of information, analysis, synthesis, classification, differentiate relevant information from the irrelevant, among others. It is important to work on the reading comprehension stage and strengthened at the literal and inferential levels first, and then obtained positive results at the critical reading stage.

The findings found will be useful to develop the following aspects: First, to improve the application of the program with the use of children's literature as a teaching resource, as well as the texts and instruments to assess it; and apply the assessment strategies and instruments in the students in the seventh year, in order to improve their reading comprehension skills and consequently their learning levels. Reading comprehension is not the result of decoding. To achieve it, it is necessary to develop comprehension strategies together with the decoding act. For example, working with preschool on phonological awareness and oral language simultaneously promotes comprehension.

In summary, it is important to emphasize the role of understanding and start working on the skills that are the base from an early age, in order to give children more opportunities to learn. Lack of comprehension closes doors, and that is what we need to fight. Finally, these intervention studies do not only help to improve reading comprehension skills but also aid to enhance text comprehension;also they contribute to develop a fluent learning in reading, and in subsequent school years, and as such, they help address children's reading difficulties (UNESCO, 2015).

\section{REFERENCES}

[1] Álvarez, D. (Dir.). De leer. Un viaje por la promoción de lectura.University of Antioquia, Inter-American School of Library Science, Medellín, 2008.

[2] Cain, K. Text comprehension and its relation to coherence and cohesion in children's fictional narratives. British Journal of Developmental Psychology, 21(3), 335-351, 2003. DOI: $10.1348 / 026151003322277739$

[3] Carrasco, A. The school can teach reading strategies and promote their regular employment. Revista Mexicana de Investigación Educativa, 8 (17), 129-142, 2003.

[4] Cassany, D., Luna, M. and Sanz G. Enseñar Lengua. GRAÓ, Barcelona, 2003.

[5] Cassany, D. Tras las líneas, sobre la lectura contemporánea. Anagrama, Barcelona, 2006.

[6] Cervera, J. Around children's literature. Revista de Filología y su Didáctica, (12), 157-168, 1989.

[7] Condemarín, M. El poder de leer. Edición especial para el programa de las 900escuelas. Ministerio de Educación, Chile, Santiago, 2001.

[8] Chong-Siu, R. What is children's literature and how much does it matter what it is? Revista de Bibliotecologia y Ciencias de la Información, 3 (11), 1-4, 2002.

[9] Flores, A. and Gallego, T. Development of reading comprehension skills in elementary school boys and girls. Revista Virtual Universidad Católica del Norte, (51), 23-45, 2017.

[10] Gil, L. and Flores, R. Development of inferential thinking skills and reading comprehension in children from three to six years old. Panorama, 9, 103-125, 2011.

[11] Gómez J. Reading comprehension and school performance: a route to improve education.Revista de Investigación en Comunicación y Desarrollo, 2 (2), 27-36, 2011.

[12] Gordillo, A., and Flores, M. The levels of reading comprehension: towards an investigative and reflective statement to improve reading comprehension in university students. Revista Actualidades Pedagógicas, (53), 95-107, 2009.

[13] Guerrero, G. Lecturas viajeras. Ianau Editora, Quito, Ecuador, 2017.

[14] Gutiérrez, E. Digital reading: reading in the environment of new information and communication technologies. Signo y Pensamiento, 28 (54), 144-163, 2009.

[15] Hagg, C. Predictors in Reading and Writing in Mexican Subjects in Primary Education (doctoral thesis). Malaga University, España, 2017.

[16] Hernández, R., Fernández, C., and Baptista, M. Metodología de la investigación. McGraw-Hill, México, 2014.

[17] Herrera, L., Hernández, G., Valdés, É., and Valenzuela, N Reading comprehension level in the secondary level in subsidized private schools in Talca. Educational Forum, 25, 125-142. 2015: DOI: 10.29344/07180772.25.815

[18] Hoyos, A. and Gallego, T. Development of Reading Comprehension Skills in Primary School Children. Revista Virtual Universidad Católica del Norte, 51, 23-45, 2017.

[19] Hurtado, R., Serna, D., and Sierra, L. Lectura con sentido: estrategias para mejorar la comprensión textual. Escuela Normal Superior María Auxiliadora de Copacabana, Colombia, 2001.

[20] INEVAL Informe de resultados "Ser bachiller". Ciclo 2018-2019, Quito, INEVAL, 2019.

[21] McNamara, D. Learning from text: Effects of text structure and reader strategies. RevistaSignos, 37 (55), 19-30, 200). DOI: $10.4067 / \mathrm{S} 0718-09342004005500002$

[22] Millán, N. Didactic model for the comprehension of texts in basic education. Revista de Teoría y Didáctica de las Ciencias Sociales, 16, 109-133, 2010.

[23] Molina, M. The literary bases of reading comprehension. Revista Publicaciones, (32), 85-103 (2002).

[24] Muñoz, A. and Ocaña, M. The Use of Metacognitive 
Strategies to Enhance Reading Comprehension Skills Cuadernos de Lingüística Hispánica, (29), 223-244, 2017. DOI:

http://dx.doi.org/10319053/01211053X.n29.2017.5865.

[25] Palacios, M. Leer para Pensar, Búsqueda y Análisis de la Información.Longman, México (1995).

[26] Pellicer, A. and Vernon, S. Entre el texto y el lector: la creación de mundo posible. Lectura y vida. Revista Latinoamericana de lectura, 14 (2), 1-10, 1993.

[27] Quiroga, H. El almohadón de plumas. Ciudad Seva, 1917. Recovered from https:/ciudadseva.com/texto/el-almohadon-de-plumas/

[28] Quiroga, H. Las medias de los flamencos. Ciudad Seva, 1918. Recovered from https://ciudadseva.com/texto/las-med ias-de-los-flamencos/

[29] UNESCO. Informe de resultados TERCE. Tercer estudio regional y comparativo. Estudio Logros de aprendizaje, Ecuador. Santiago, Chile: Oficina Regional de Educación de la UNESCO para América Latina y el Caribe. (2015). Disponible en http://www.unesco.org/new/fileadmin/MUL TIMEDIA/FIELD/Santiago/pdf/Ficha-Logros-del-Aprendiz aje-Ecuador.pdf.

[30] UNESCO. El Laboratorio Latinoamericano de Evaluación de la Calidad de la Educación (LLECE). Los aprendizajes de los estudiantes de América Latina y el Caribe, Santiago de Chile, UNESCO, 2015.

[31] Yubero, S., and Larrañaga, E. The value of reading in relation to reading behavior. A study on reading habits and lifestyle in children. Revista OCNOS, 6 (6), 7-20, 2010. 